(C) Elsevier/Inra

\author{
Original article
}

\title{
Support for single major genes influencing fat androstenone level and development of bulbo-urethral glands in young boars
}

\author{
MN Fouilloux ${ }^{1}$, P Le Roy ${ }^{1}$, J Gruand ${ }^{2}$, C Renard ${ }^{3}$, \\ P Sellier ${ }^{1}, \mathrm{M}$ Bonneau ${ }^{4}$ \\ 1 Station de génétique quantitative et appliquée, \\ Institut national de la recherche agronomique, 78352 Jouy-en-Josas cedex; \\ 2 Station expérimentale de sélection porcine, \\ Institut national de la recherche agronomique, 86480 Rouillé; \\ ${ }^{3}$ Laboratoire de radiobiologie appliquée, Institut national de la recherche agronomique - \\ Commissariat à l'énergie atomique, 78352 Jouy-en-Josas cedex; \\ 4 Station de recherches porcines, Institut national de la recherche agronomique, \\ 35590 Saint-Gilles, France
}

(Received 21 April 1997; accepted 5 June 1997)

\begin{abstract}
Summary - A two-step genetic analysis was performed on data collected in a fourgeneration selection experiment comprising a control and a selected line in a Large White-Landrace crossbred population. The two-trait selection index used for choosing replacement boars of the selected line included fat androstenone level and the average thickness of right and left bulbo-urethral glands, the latter trait being an indicator of the sexual maturity status of young boars. Fat androstenone level was determined on a biopsy sample of backfat taken at $118 \mathrm{~kg}$ liveweight, whereas bulbo-urethral gland size was measured by echotomography, using a rectal probe, at $99 \mathrm{~kg}$ liveweight. A total of 949 entire males, from 57 sires and 353 dams, were recorded for both traits. In the first step of analysis, REML genetic parameters were estimated using a bivariate animal model. Heritability estimates $( \pm \mathrm{SE})$ were $0.55 \pm 0.07$ for fat androstenone level and $0.63 \pm 0.05$ for bulbo-urethral gland size. A fairly close genetic correlation $(0.68 \pm 0.05)$ was found between the two traits. The second step of analysis consisted in testing the hypothesis of a mixed mode of inheritance (polygenes + major gene) for each trait using segregation analysis methods. A major two-allele gene was found to affect fat androstenone level. Under the genetic model that best explained the situation, the 'low androstenone' allele $(L)$ is completely dominant over the 'high androstenone' allele $(H)$, and the difference between $H H$ and $L L$ (or $H L$ ) genotypes amounts to three SD units of the trait. A twoallele major gene was also shown to influence bulbo-urethral gland size (difference close to two SD units between the two homozygous genotypes) with a probably incomplete dominance of the 'small size' allele. There was no evidence for linkage of these genes with
\end{abstract}


the swine leukocyte antigen (SLA) system. Whether these two postulated major genes are a unique gene or not is discussed.

pig / androstenone / sexual maturity / genetic parameter / major gene

Résumé - Mise en évidence de gènes à effet majeur sur la teneur en androsténone du gras et le développement des glandes bulbo-uréthrales chez le jeune verrat. Cette étude concerne une analyse génétique, en deux étapes, des données recueillies dans les quatre générations d'une expérience de sélection comportant une lignée témoin et une lignée sélectionnée dans une population croisée à base de Large White et de Landrace. L'indice à deux caractères utilisé pour le choix des verrats de la lignée sélectionnée combinait la teneur en androsténone du gras et l'épaisseur moyenne des glandes bulbo-uréthrales droite et gauche, ce dernier caractère étant un indicateur du statut de maturité sexuelle des jeunes verrats. La teneur en androsténone a été mesurée sur une biopsie de gras dorsal prélevée $\grave{a} 118 \mathrm{~kg}$ de poids vif alors que le développement des glandes bulbo-uréthrales a été mesuré par échotomographie, à l'aide d'une sonde rectale, à $99 \mathrm{~kg}$ de poids vif. Au total, 949 mâles entiers, issus de 57 pères et 353 mères, ont été mesurés pour l'un et l'autre caractère. Dans la première étape de l'analyse, les paramètres génétiques des deux caractères ont été estimés à l'aide d'une procédure REML appliquée à un modèle animal bicaractère. Les estimées d'héritabilité ( \pm erreur standard) sont $0,55 \pm 0,07$ pour la teneur en androsténone du gras et 0,63 $\pm 0,05$ pour l'épaisseur moyenne des glandes bulbo-uréthrales. Une corrélation génétique relativement élevée $(0,68 \pm 0,05)$ a été trouvée entre les deux caractères. Une seconde étape de l'étude a consisté à tester, à l'aide de méthodes d'analyse de ségrégation, l'hypothèse d'un déterminisme génétique mixte (polygènes + un gène majeur) pour chaque caractère. Un gène à effet majeur sur la teneur en androsténone du gras a été mis en évidence : selon le modèle génétique le plus explicatif, l'allèle «faible» (L) est complètement dominant sur l'allèle «fort» (H), avec une différence entre les génotypes $H H$ et LL (ou $H L)$ voisine de trois écarts types phénotypiques du caractère. Un gène à effet majeur sur l'épaisseur moyenne des glandes bulbo-uréthrales (différence de l'ordre de deux écarts types phénotypiques entre les génotypes homozygotes) a également été mis en évidence avec une dominance probablement incomplète de l'allèle "faible». Ces deux gènes ne semblent pas être liés avec le système d'histocompatibilité majeur (SLA). La possible identité des deux gènes majeurs postulés est discutée

porc / androsténone / maturité sexuelle / paramètre génétique / gène majeur

\section{INTRODUCTION}

In spite of the well-known adverse effects of castration of male pigs on lean tissue growth rate and food conversion, pork production from entire males is discouraged in most countries, especially in those practising heavier slaughter weights of market pigs. The reason for this policy is that unpleasant odours (referred to as boar taint) occur during the cooking of meat from some boars. Androstenone (5a-androst-16en-3-one) is one of the major compounds contributing to boar taint. This C19D16 steroid, exhibiting an intense urine-like odour, is synthesized in the testes of puberal boars, then released into the blood and finally stored in the adipose tissue. Reported coefficients of correlation between fat androstenone level and boar taint intensity, as assessed by laboratory panels, average 0.55 (range: $0.4-0.8$ ) according to the survey of Bonneau (1993).

As reviewed by Willeke (1993), fat androstenone level in boars of a given weight or age is a highly heritable trait and has been successfully selected for. However, 
the extent to which genetic variation in this trait is associated with genetic factors influencing the sexual development of the boar or is dependent on the proper genetic capacity for C19D16 steroid synthesis in the puberal boar remains to be evaluated. A selection experiment has been carried out in an attempt to answer the question as to whether it is possible or not to decrease fat androstenone levels in a population of boars without affecting the sexual maturity status of these boars, the latter being appraised by the size of bulbo-urethral glands at a fixed liveweight.

The purpose of this note is to report estimates of genetic parameters for the two traits included in the selection index as well as segregation analysis results providing evidence for major genes influencing the same two traits. Moreover, a linkage between a QTL having large effects on fat androstenone level and the major histocompatibility complex of the pig (SLA) was recently reported by Bidanel et al (1996) in the $\mathrm{F}_{2}$ generation of the Meishan by Large White cross, whereas significant associations of some SLA haplotypes with male genital tract development had earlier been found by Rothschild et al (1986). Information on serologically defined SLA haplotypes was available for part of the animals of the present experiment and was taken into account in further segregation analyses.

\section{MATERIAL AND METHODS}

\section{Animals and traits}

The present data set deals with a four-generation selection experiment conducted over the years 1988-1993 at the INRA experimental farm of Rouille (Vienne, France). From a foundation stock $\left(\mathrm{G}_{0}\right)$ consisting of 141 Large White $\times$ Landrace $\left(F_{1}\right)$ entire males sired by 18 different boars, two lines of boars have been established: an unselected control line (C) and a selected line (S). In the line S, replacement boars (one generation per year) were chosen among animals showing the highest values of a selection index including the following two traits:

- the average thickness of right and left bulbo-urethral glands ( $B$ in $\mathrm{mm}$ ), measured by echotomography using a rectal probe on the live animal at $99.1 \pm$ $2.7 \mathrm{~kg}$ liveweight (average age: 162 days). The correlation of that live thickness measurement with the weight of bulbo-urethral glands measured after slaughter a few days later was 0.86 in a sample of 175 boars (Sellier et al, 1993);

- the androstenone content of a small biopsy sample of backfat removed from the neck region at $117.6 \pm 2.4 \mathrm{~kg}$ liveweight (average age: 185 days). Androstenone content (in ppm) was determined using the radioimmunoassay procedure described by Bonneau and Russeil (1985). A logarithmic transformation was used so that the variable included in the selection index was $A=\log$ (androstenone content $\times 10^{2}$ ).

The two-trait selection index $(I=100-63 A+4 B)$ had been established with the objective of decreasing $A$ while maintaining a normal sexual maturity status (ie, no expected genetic change in $B$ ). The line $\mathrm{C}$ comprised four or five randomly chosen sires and, on average, $23 \mathrm{~F}_{1}$ dams in each generation. The corresponding numbers for the line $\mathrm{S}$ were five and 48 , respectively. For more details on the design of this experiment, see Sellier et al (1993).

A total of 949 candidate boars, from 57 sires and 353 dams, were recorded for both traits $A$ and $B$ throughout the experiment. In addition, serological SLA class I 
typing was performed on boars belonging to the foundation stock $\mathrm{G}_{0}$ and to generations 1 and 2 . The SLA class I antigens were defined by microlymphocytotoxicity testing as described by Renard et al (1988). Animals were typed by means of panels of 100 alloantisera, which allowed identification of 18 internationally defined SLA specificities (B1, B3, B11, W2, W4-W10, W12-W18) and 15 locally defined specificities (FJ1, D4, FJ4, FJ13, DB19, FJ20, SB22, FJ23, FJ25, FJ27, FJ28, DC31, FJ33, FJ35 and FJ39). For investigating the linkage of SLA with the postulated major genes, the number of informative meioses was 441 .

\section{Statistical analyses}

In the first step of the analyses, heritabilities and phenotypic and genetic correlations for fat androstenone level and bulbo-urethral gland size were estimated by a bivariate REML animal model procedure using the VCE (variance component estimation) package (Groeneveld and Kovac, 1990). The mixed model of analysis included the fixed effect of year, the live weight at measurement as a covariate, the random effects of litter and animal additive genetic value and the random residual effect. Pedigree information on males, starting from $\mathrm{G}_{0}$, was used to calculate the inverse of the numerator relationship matrix. The distribution of fat androstenone levels was far from being normal, mainly owing to its marked skewness, and a suitable Box-Cox power transformation (MacLean et al, 1976) was used for removing deviation from normality prior to REML analysis (fig 1).

In a second step, segregation analyses (Elston and Stewart, 1971) were performed for both traits. Considering the results of some preliminary analyses (Fouilloux, 1995), the presence of major genes with large effects could indeed be suspected for several reasons such as the very high realized heritability for size of bulbourethral glands (mainly owing to a surprisingly sharp increase in the line $\mathrm{S}$ between generations 2 and 3 ) and some evidence for mixture of distributions for fat androstenone level. Analyses were carried out separately for each trait as a multivariate approach was precluded owing to computing cost considerations. Several tests were performed. First, the hypotheses of mixed inheritance $\left(\mathrm{H}_{1}\right.$, polygenes and one two-allele major gene) and polygenic inheritance $\left(\mathrm{H}_{0}\right)$ were compared. The conclusion of this test (ie, the existence of a major gene) led us to consider other hypotheses of mixed inheritance: a model in which one allele of the major gene is completely dominant over the second one (hypothesis $\mathrm{H}_{1}^{\prime}$ ) and then models assuming linkage between the major gene and the SLA locus (hypotheses $\mathrm{H}_{2}$ and $\mathrm{H}_{2}^{\prime}$ ). The latter hypotheses were tested by use of the method described by Le Roy and Elsen (1992). This method implies that the recombination rate between SLA and the major gene is a parameter to be estimated as all other parameters of the model. All segregation analyses of fat androstenone level were carried out with a simultaneous Box-Cox transformation of the residues of the model (Morton et al, 1978). Using a transformation to remove skewness induced by a major gene is expected to increase the robustness of the segregation analysis, but this also leads to a loss of power (Demenais et al, 1986). Moreover, the pedigree submitted to analysis was simplified, as it was considered as a set of independent sire families. 


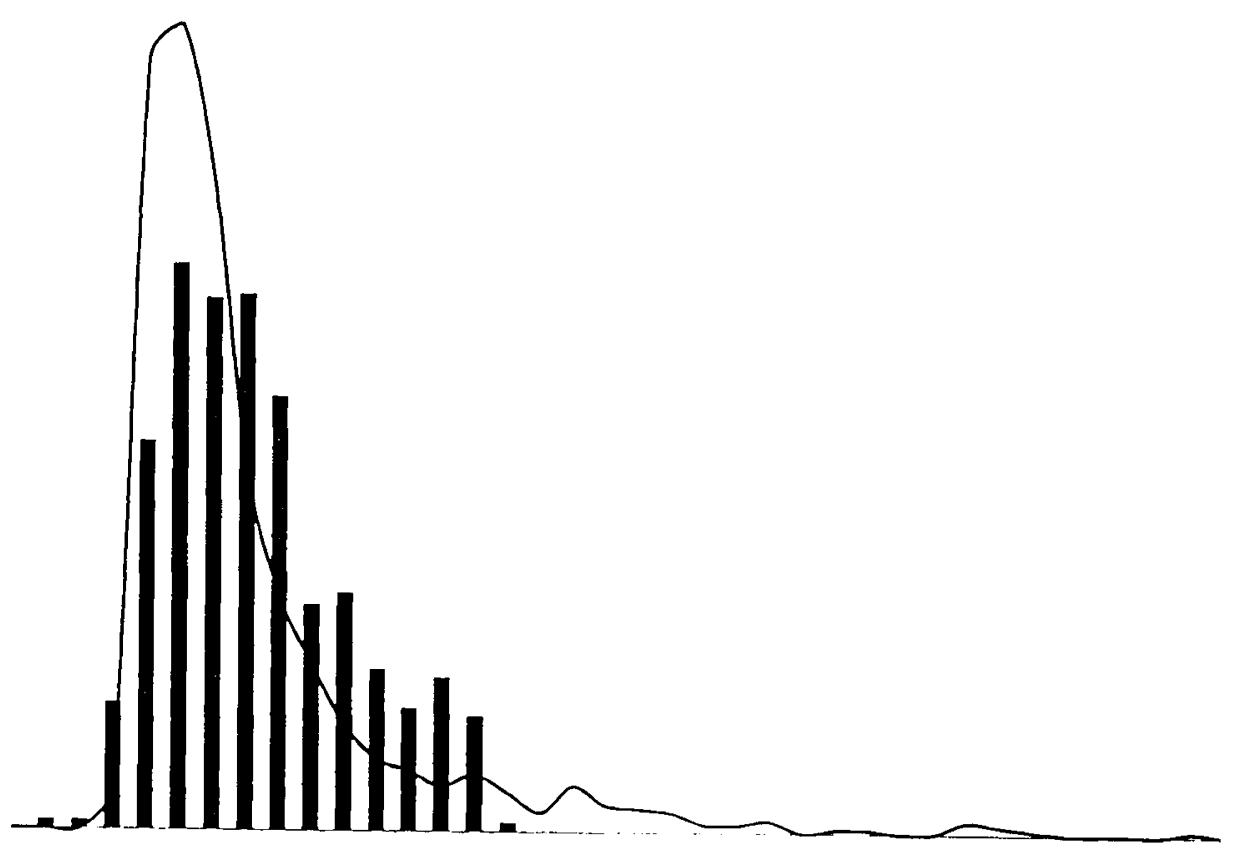

Fig 1. Frequency distributions of 'raw' data (curve) and 'Box-Cox transformed' data (vertical bars) for fat androstenone level.

\section{RESULTS AND DISCUSSION}

\section{Genetic parameters}

Heritability $\left(h^{2}\right)$ and common environmental effect $\left(c^{2}\right)$ estimates are $h^{2}=0.55 \pm$ 0.07 and $c^{2}=0.02 \pm 0.03$ for fat androstenone level, and $h^{2}=0.63 \pm 0.05$ and $c^{2}=0.04 \pm 0.02$ for size of bulbo-urethral glands. Estimated phenotypic and genetic correlations between the two traits are $0.38(P<0.001)$ and $0.68 \pm 0.05$, respectively.

The present $h^{2}$ estimate for fat androstenone level is higher than the value of 0.25 reported by Jonsson and Andresen (1979) and is close to the lower bound of the range of values $(0.54-0.88)$ found for the same trait (Bonneau and Sellier, 1986; Willeke et al, 1987; Sellier and Bonneau, 1988) or for boar taint intensity score (Jonsson and Wismer-Pedersen, 1974).

The $h^{2}$ estimate found here for bulbo-urethral gland size is substantially larger than the average value (around 0.4) of earlier estimates reported for traits pertaining to male genital tract development at a constant body weight or age, such as testis size (appraised on the live animal) or weights of testes, epididymes, seminal vesicles and bulbo-urethral glands (measured after slaughter): see Legault et al (1979), Toelle et al (1984), Bonneau and Sellier (1986), Sellier and Bonneau (1988) and 
Johnson et al (1994). In the latter study, ten generations of upward selection for predicted testis weight at 150 days of age were carried out in a Large WhiteLandrace composite population, and the realized heritability of testis weight was only $0.35( \pm 0.02)$.

Regarding the relationships between fat androstenone level and bulbo-urethral gland size, the phenotypic correlation found here is quite similar to that reported by Bonneau and Sellier (1986). The present estimate of genetic correlation falls within the range of values $(0.25-0.91)$ found in young boars for various genital tract measurements by Bonneau and Sellier (1986) and Sellier and Bonneau (1988). The latter authors reported a genetic correlation of 0.60 between testis size at $104 \mathrm{~kg}$ liveweight and fat androstenone level at $124 \mathrm{~kg}$ liveweight, which is in good agreement with the estimate found here with comparable stages of measurement for the respective traits.

The present estimates of genetic parameters thus differ from those of previous studies only by the higher heritability of the sexual maturity indicator.

\section{Segregation analysis}

The results of various segregation analyses are given in table I for fat androstenone level and bulbo-urethral gland size. For both traits, the likelihood ratio referring to the $\mathrm{H}_{1}$ versus $\mathrm{H}_{0}$ comparison is significant at the $P<0.001$ level. The polygenic inheritance hypothesis must be rejected, showing that, whatever the trait, a major single gene was also segregating in the population studied.

For fat androstenone level, the genetic model that best explained the situation under the mixed inheritance hypothesis appears to be the model $\mathbf{H}_{1}^{\prime}$ in which the 'low androstenone' allele $(L)$ is completely dominant over the 'high androstenone' allele $(H)$. There is no indication of a linkage between this postulated major gene and the SLA system. The likelihood ratios referring to the $\mathrm{H}_{2}^{\prime}$ versus $\mathrm{H}_{1}^{\prime}$ or $\mathrm{H}_{2}$ versus $\mathrm{H}_{1}$ comparisons are not significant ( 0.5 and 0.7 , respectively), indicating that the estimate of recombination rate $\left(0.36\right.$ for $\left.\mathrm{H}_{2}^{\prime}\right)$ does not differ from 0.5 .

For bulbo-urethral gland size, the mixed inheritance model in which the complete dominance of the 'small size' allele is assumed (hypothesis $\mathrm{H}_{1}^{\prime}$ ) is also the most acceptable, but the likelihood ratio referring to the model in which no restriction is imposed on the dominance parameter for the major gene $\left(\mathrm{H}_{1}\right.$ versus $\mathrm{H}_{1}^{\prime}$ comparison) is marginally significant, at the $P<0.10$ level (3.4). The complete dominance of the 'small size' allele cannot therefore be considered as definitely proven. The likelihood ratios referring to the $\mathrm{H}_{2}^{\prime}$ versus $\mathrm{H}_{1}^{\prime}$ or $\mathrm{H}_{2}$ versus $\mathrm{H}_{1}$ comparisons (0.6 and 0.2 , respectively) are not significant. On this basis, the linkage between the SLA system and the postulated major gene affecting bulbo-urethral gland size can be ruled out.

The average daily gain and ultrasonic backfat thickness were submitted to a segregation analysis $\left(\mathrm{H}_{1}\right.$ versus $\mathrm{H}_{0}$ test) using the same data set (results not shown), and it was concluded that the polygenic inheritance hypothesis is not to be rejected for these two performance traits.

The maximum likelihood estimates of the parameters for fat androstenone level show that the difference between the mean values of the $L L$ (or $L H$ ) and $H H$ genotypes amounts to around three phenotypic standard deviation units of the trait for the 'Box-Cox transformed' data. Corresponding genotype means on the 


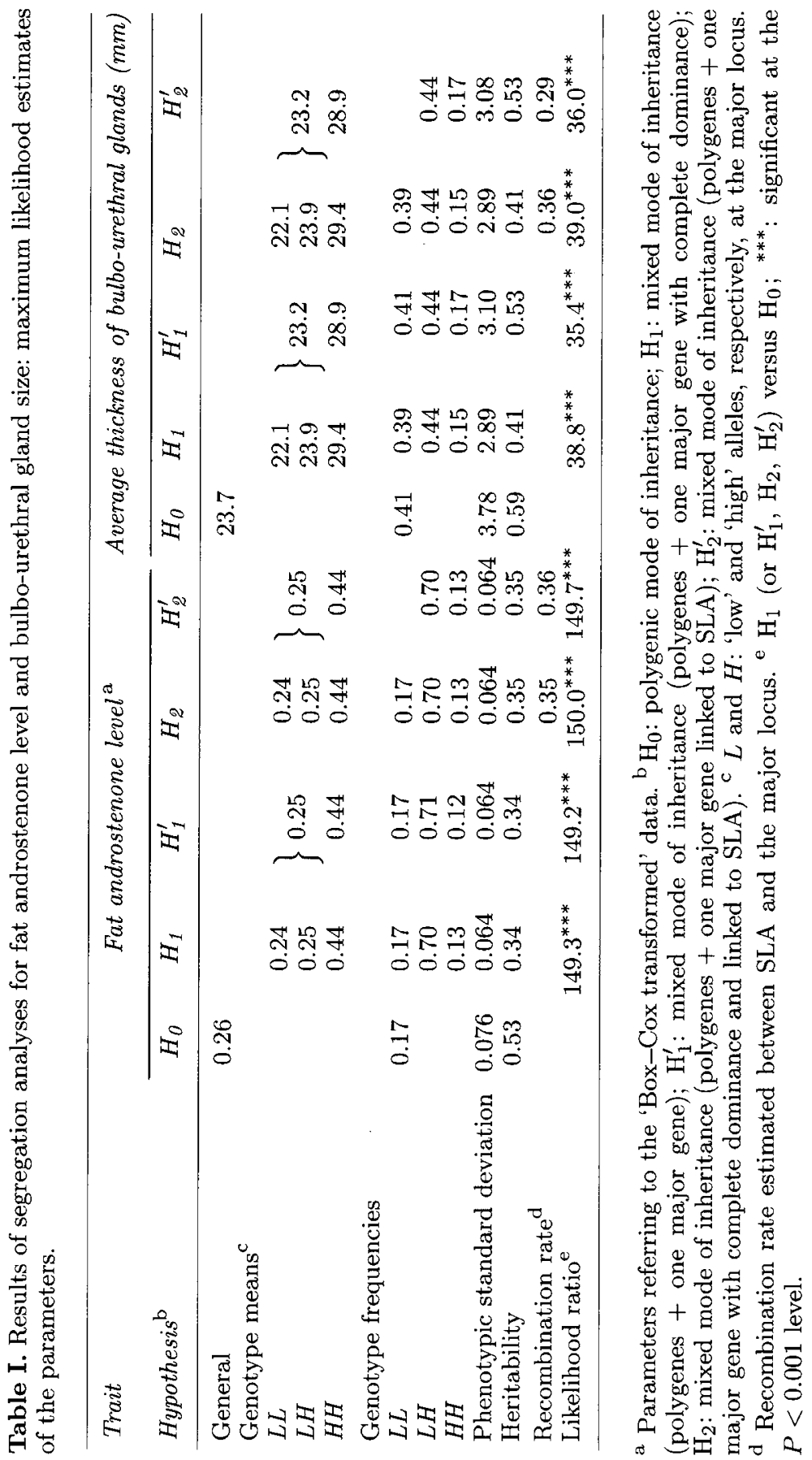


original scale of measurement (after reverse transformation) are $0.33 \mathrm{ppm}$ for $L L$ (or $L H)$ and $0.90 \mathrm{ppm}$ for $H H$. The maximum likelihood estimates of the parameters for bulbo-urethral gland size show that the difference between the mean values of the two homozygous genotypes amounts to around two phenotypic standard deviation units of the trait. It is noteworthy, that the heritability estimates under the polygenic inheritance hypothesis are, whatever the trait, close to those found in the REML animal model analysis. On the other hand, it should be pointed out that the 'residual' heritabilities under the mixed inheritance hypothesis remain fairly high (around 0.4 for both traits).

Fat androstenone levels are determined by the balance between the intensities of testicular androstenone synthesis and androstenone degradation (Bonneau et al, 1982). The intensity of androstenone biosynthesis depends on sexual maturity and on the activity of andien-b-synthase, the enzyme system leading to the C19D16 steroids biosynthesis pathway (Gower, 1972). It may be speculated that there is evidence for a major gene in the present study, which could regulate the activity of andien-b-synthase, whereas the remaining polygenic variation could correspond to differences between animals in their capacity to catabolize androstenone. The existence of such differences has been postulated from previous results (Claus, 1976; Bonneau et al, 1982). Alternatively, the fairly close genetic correlation between fat androstenone level and bulbo-urethral gland size could result from the presence of a unique major gene influencing androstenone synthesis through sexual maturity. Considering the predicted genotypes of individuals at the two postulated loci would suggest that the respective genotypes do not agree in most cases, but the number of individuals whose genotypes at both major loci are known with a reasonably high probability (more than 0.80 ) is quite limited. More generally, the poor accuracy of the prediction of individual genotypes at each postulated major locus does not make it possible to verify the coherence between parent and offspring genotypes nor to compare the time trends of allelic frequencies in control and selected lines. Only a specific experiment relying on planned matings between animals of well-determined genotype would permit the confirmation of the results of this study.

The finding of a major gene affecting fat androstenone level gives rise to new prospects for reducing incidence of boar taint by means of breeding. The average level of individuals carrying the 'low androstenone' allele at the postulated major locus is indeed well below the critical threshold value of $1 \mathrm{ppm}$. Avoiding boar taint in a pig population would hopefully be obtained by fixing this allele. However, the expected consequences on sexual maturity status of boars remain uncertain as the possible identity of the two major loci detected independently for each trait could not be accurately tested at this stage of the study.

\section{ACKNOWLEDGMENTS}

Thanks are expressed to $\mathrm{F}$ Bariteau and $\mathrm{J}$ Bussière (Station expérimentale d'insémination artificielle, Rouillé, France) for their efficient contribution to the achievement of this selection experiment. The expert technical assistance of J Portanguen and F Giovanni, who performed the androstenone determinations, is gratefully acknowledged. This experiment was supported by grants from AIP 'Constitution de lignées génétiquement intéressantes' and from INRA 'Direction Scientifique des Productions Animales'. 


\section{REFERENCES}

Bidanel JP, Milan D, Chevalet C, Woloszyn N, Caritez JC, Gruand J, Le Roy P, Bonneau M, Renard C, Vaiman M, Gellin J, Ollivier L (1996) Mapping quantitative trait loci in a Meishan $\times$ Large White $\mathrm{F}_{2}$ population. In: Book Abstr. 4 th EAAP Ann Meeting (Van Arendonk JAM, ed), Wageningen Pers, Wageningen, 40 (abstr)

Bonneau M (1993) Effects of different compounds on boar taint. In: Proc 44th EAAP Ann Meeting, Aarhus, Denmark, 16-19 August 1993, 326-327 (abstr)

Bonneau M, Russeil P (1985) The use of Cowper's (bulbo-urethral) glands as an estimate of boar taint on the slaughter line. Livest Prod Sci 13, 169-178

Bonneau M, Sellier P (1986) Fat androstenone content and development of genital system in young Large White boars: genetic aspects. World Rev Anim Prod 22, 27-30

Bonneau M, Meusy-Dessolle N, Léglise PC, Claus R (1982) Relationships between fat and plasma androstenone and plasma testosterone in fatty and lean young boars following castration. Acta Endocrinol (Copenhagen) 101, 129-133

Claus R (1976) Messung der Ebergeruchtsstoffes im Fett von Schweinen mittels eines Radioimmunotests. 2. Mitteilung: Zeitlicher Verlauf des Geruchdepotabbaues nach der Kastration. Z Tierz Züchtungsbiol 93, 38-47

Demenais F, Lathrop M, Lalouel JM (1986) Robustness and power of the unified model in the analysis of quantitative measurements. Am J Hum Genet 38, 228-234

Elston RC, Stewart J (1971) A general model for the genetic analysis of pedigree data. Hum Hered 21, 523-542

Fouilloux MN (1995) Etude du déterminisme génétique du taux d'androsténone du gras chez le verrat. Maîtrise de BGA (Université Paris 7), Sgqa, Jouy-en-Josas

Gower DB (1972) 16-unsaturated C19 steroids - a review of their chemistry, biochemistry and possible physiological role. J Steroid Biochem 3, 45-103

Groeneveld E, Kovac M (1990) A note on multiple solutions in multivariate restricted maximum likelihood covariance component estimation. J Dairy Sci 73, 2221-2229

Johnson RK, Eckardt GR, Rathje TA, Drudik DK (1994) Ten generations of selection for predicted weight of testes in swine: direct response and correlated response in body weight, backfat, age at puberty, and ovulation rate. J Anim Sci 72, 1978-1988

Jonsson P, Andresen O (1979) Experience during two generations of within lines performance testing, using 5a-androst-16-ene-3-one (5a-androstenone) and an olfactory judgement of boar taint. Ann Génét Sél Anim 11, 241-250

Jonsson P, Wismer-Pedersen J (1974) Genetics of sex odour in boars. Livest Prod Sci 1, $53-66$

Legault C, Gruand J, Oulion F (1979) Mise au point et intérêt génétique d'une méthode d'appréciation sur le vivant du poids des testicules chez le jeune verrat. In: 11es Journées de la Recherche Porcine en France, Paris, 31 janvier-2 février 1979, Institut technique du porc, Paris, 313-322

Le Roy P, Elsen JM (1992) Numerical comparison between analysis of variance and maximum likelihood methods for QTL detection in progeny test designs. In: Proc 43rd EAAP Ann Meeting, Madrid, Spain, 14-17 September 1992, vol 1, 68-69 (abstr)

MacLean CJ, Morton NE, Elston RC, Yee S (1976) Skewness in commingled distributions. Biometrics 32, 695-699

Morton NE, Guldbrandsen CL, Rhoads GG, Kagan A, Lew R (1978) Major loci for lipoprotein concentrations. Am J Hum Genet 30, 583-589

Renard C, Kristensen B, Gautschi C, Hruban V, Fredholm M, Vaiman M (1988) Joint report of the first international comparison test on swine lymphocyte alloantigens (SLA). Anim Genet 19, 63-72 
Rothschild MF, Renard C, Sellier P, Bonneau M, Vaiman M (1986) Swine lymphocyte antigen (SLA) effects on male genital tract development and androstenone level. In: Proc 3rd World Cong Genet Appl Livest Prod (Dickerson GE, Johnson RK, eds), University of Nebraska, Lincoln, Nebraska, vol 11, 197-202

Sellier P, Bonneau M (1988) Genetic relationships between fat androstenone level in males and development of male and female genital tract in pigs. J Anim Breed Genet 105, $11-20$

Sellier P, Bonneau M, Gruand J (1993) Preliminary results of a selection experiment based on an index associating fat androstenone level and bulbo-urethral gland size. In: Measurement and Prevention of Boar Taint in Entire Male Pigs (Bonneau M, ed), Inra, Paris, Les Colloques No 60, 173-178

Toelle VD, Johnson BH, Robison OW (1984) Genetic parameters for testes traits in swine. J Anim Sci 59, 967-973

Willeke H (1993) Possibilities of breeding for low 5a-androstenone content in pigs. Pig News Info $14,31 \mathrm{~N}-33 \mathrm{~N}$

Willeke H, Claus R, Müller E, Pirchner F, Karg H (1987) Selection for high and low level of 5a-androst-16-en-3-one in boars. I. Direct and correlated response of endocrinological traits. J Anim Breed Genet 104, 64-73 